\title{
Review on How Technology Has Impacted the Global Business Environment
}

\author{
Article by Natasha Adatia \\ Texila American University (DSM-TZ) \\ E-mail: natashadatia@hotmail.com
}

\begin{abstract}
This research looks at the work of Oneil Williams, the editor of Opposing Views. The purpose of this article is to understand the concept of the global business environment in relation to the recent advances in technology. As we all know, technology has been one of the major components for organizations operating globally, therefore it is through this article that I was able to highlight the importance of keeping up to date with your technology in order to thrive in the global market. Apart from the theoretical knowledge produced, the article review further analyses the article "How has technology impacted the global business environment?" in terms of its structure, accuracy stability and validity. One of the other objectives of this article review is to guide individuals on how to systematically review an article.

Source: Oneil Williams. (13 ${ }^{\text {th }}$ July 2015). How Has Technology Impacted the Global Business Environment? Available: http://science.opposingviews.com/technology-impactedglobal-business-environment-1372.html. Last accessed 08th January 2016.
\end{abstract}

\section{Introduction}

According to the National Science Foundation, technology-focused companies are successful in foreign markets and develop high value added products. However, Technology is not without drawbacks. Many would argue that the advantages of operating in a global business environment outweigh the setbacks. Therefore, the intention of this Article Review is to systematically review the article "How Has Technology Impacted the Global Business Environment?”By Oneil Williams. Secondly, the article review will provide literature review from a number of scholars relating to the topic of the article. Thirdly, it will analytically review the proficiency of the articles structure, assessing the articles format and accessibility. Fourthly, the article review will intend on valuing the article in terms of its authority, currency, accuracy, objectivity and coverage. Furthermore, the article review will be appraised in terms of its accessibility and credibility. Lastly, the review will consist of a conclusion, putting forward suggested recommendations. Overall, the article can be said to be clear, legible and applicable.

\section{Article summary}

This article was published by "OPPOSINGVIEWS" in 2015 based on an article written by Oneil Williams titled "How Has Technology Impacted the Global Business Environment?" The article additionally contained data from the National Science Foundation.

According to Oneil Williams, "Globalization has forced companies to engage in strategic planning in order to grow their businesses and compete in an international marketplace". Therefore, the article intends on sharing knowledge with its readers on how technology has impacted the global business environment in both a positive and a negative way. The article provides evidence through including examples of other internationally successful organizations and how the increase in competitiveness has opened opportunities for high-tech jobs. The article further provides information on the drawbacks of how technology has impacted the employment rate in other countries and forced lower wages, further pointing out the importance of strategic planning for companies who wish to grow their organizations and compete in the global business environment. Overall, the publisher has provided 
South American Journal of Management

Volume 2, Issue 1, 2016

knowledgeable information that could direct organizations to promote and ensure that their organization can further continue to be a leading provider in its market. The article "How Has Technology Impacted the Global Business Environment?" consist of the following subtitles: Competitiveness; Lower Wages; High-tech Jobs and Strategic Planning.

\section{Review of literature}

The article presented inadequate literature in support of the subject. However, the following literature relating to this article can be summarized as below:

The 21st century presented without doubt the biggest changes, progresses in technology, and its effects on organizations. According to Brooks, Weatherston, \& Wilkinson (2010) reasoning, the use of or lack of use of technology has a strong influence upon the competitiveness of firms, sectors and nations. Nevertheless, Seitz \& Hite (2011) points out that the wrong use of technology can conversely cause harm to the world.

According to Dunne, T., M.J. Roberts, and L. Samuelson (1988), technology brings both tangible and intangible benefits to become cost efficient and to meet the rising wants and needs of customers. Technological innovations affect the culture, corporate productivity, relationship among employees, suppliers, clients and customers. Similarly, Madhok, A. (1998) states that the future of our organizations success will depend upon our ability to use technology to provide products and services that provide accessibility to customers and to create additional efficacies in the processes. Many competitors have substantially greater resources to invest in technological improvements. To support this, Pearce, J., \& Robinson, R. (2005) states that the vigorous growth of technology requires speedy reaction by businesses in order to survive in an emerging competitive environment and keep up with new developments and inventive services which other competitors might be offering. These include both products and processes that can bring out opportunities and threats. However it is essential for organizations who want to create a competitive advantage and survive in the global business environment.

However, according to Melissa Centurio Lopes (2000), even though technology can be useful, its fast pace and intricate systems can be perplexing. If companies want to upgrade their systems or modify the type of technology used, they have to reeducate both their employees and customers. To support to this, Acemoglu, D., Johnson, S. and J. A. Robinson (2001), stated that these advancements in technology makes it difficult for businesses to keep up with technological change whilst increasing the number of competitors in their market. lapper, L., and I. Love, (2004), also states that technology upsurges the chances of crime. An employee with wrong intentions can pilfer funds and make it challenging for the company to trace.

\section{Article structure}

The article was brought up as an abstract, which built-in the theory and key points developed by the article. The article provide informational data supported by the article, succinctly explaining the core reason under which the article and research was executed. The paragraphs were short in structure and therefore the information provided on each paragraph was easily accessible and decipherable. However there were only four subheadings, which meant that the article provided little but crucial information under each subheading. Each subheading, on the other hand provided excerpts and comparative information that further provided concrete evidence in relation to the topic. A few sections provided examples of a few organizations operating in the global business environment and their outcomes. Such analysis can make the reliability and validity of the article resilient.

The article however did not provide a conclusion as such, therefore the article lacked a comprehensive summary. The last subheading named "Strategic Planning" proposed a recommendation that stated on the importance of strategic planning for companies operating in the global market. Both references and resources used in the article were cited at the end of the article. Overall, the article's structure was fairly established. The use of short paragraphs 
enabled the reader to access the key points without difficulty. The article was HMLT (online based) and included a few links, which further simplified the informations accessibility. The article further provided links to the author, citations and references which therefore allowed the reader to access additional information more effortlessly.

\section{Article critique}

\section{Authority}

The article "How Has Technology Impacted the Global Business Environment?" was written by Oneil Williams in 2015 and further published by OPPOSING VIEWS. OpposingViews.com is a liberated site founded in 2007 that publishes original journals and articles on social issues, sports, politics, religion and entertainment with an initiative to continuously provide in-depth analysis and breaking news all year around.

The authors' credibility was also well established. The article provides a section under the article on a brief introduction about the author. Oneil Williams started writing way back in the 1993's. He wrote for "The Sunday Gleaner" and "Jamaica Observer" two newspaper publications in Jamaica. Oneil Williams's academic background shows that he holds a Bachelor of Arts and a Masters of Arts in communication from the University of Central Florida. He is known to write articles that relate to the changes taking place in the real world. Furthermore, the article also provides an acknowledgement to the photographer whose photo was used in his article.

\section{Accuracy}

The basis on which the article was integrated is based on a recent research analysis. It was published on a well-reputable site which currently has more than 25 million viewers monthly. The article was presented in an article format and was further supported by a well-known and qualified author. Furthermore, the article was secured by recent list of resources and references used in-text to promote the article and data provided. The firm editing and arbitrating processes have also contributed to the articles accuracy and efficacy. Overall, the article can termed as an accurate publication.

\section{Currency}

The article "How Has Technology Impacted the Global Business Environment?" was written by Oneil Williams and was published by OPPOSING VIEWS in 2015. OPPOSING VIEWS is a site that updates and publishes the latest news and theories all year round. The article published also relates to a research that progresses every year. I believe the information provided is current and communicates to the recent environmental changes taking place. The study it describes is an on-going subject. The article also mentions recent and informed references in the site, therefore I believe that this article is current.

\section{Relevance}

This article can be categorized as an academic material, based on an academic structure. Because the article was published by a well-recognized author and issued through a valid site, the article was high in credibility. The article was written to enrich its readers with the changes taking place in the global market and its impact on the general public. Such an academic context can be particularly helpful to those individuals who can seek for better opportunities in developed countries. Furthermore, this article can be useful to those organizations that need to understand the risks of operating in the global business environment. The government can also use this information and create barriers to entry in order to maintain the employment levels in their countries. The article would however be less relevant for well-established organizations. 
South American Journal of Management

Volume 2, Issue 1, 2016

\section{Objectivity}

The information introduced was accurately established and secured with a current research base. The article accredited all inputs from outer sources and further provided links and sites for referral purposes. The article had no such evidence of bias. The article was reinforced by the acknowledgement that the article was purely based on a research basis, and further recognized the density of the matters discussed. For example, the article talks about how the advancement of technology has forced the economy to provide jobs with lower wages and increase the rate of unemployment. The participants mentioned in the article were clearly defined as well (Toyota, McDonalds, Microsoft and Apple).

\section{Stability}

The article can be regarded as a stable publication for the reason that, the article states and provides a sufficient amount of sources and sites used in relation to the academic base of the article. Such an academic article can be identified as a stable resource.

\section{Recent advances related to the topic}

The rapid development of business globally is due to the continuous advancement in technology. Today, organizations operating globally have managed to successfully conquer language barriers, and transformed the global commerce. At this rate, the whole world can be a potential market. Customers are now able to read about and buy the goods they wish to purchase from any part of the world. Technology has also positively impacted the methods of conducting business globally, whether your business is centered in a small town or a metropolitan area like Tokyo, it can enjoy the same capabilities to run the business with anyone around the globe. Skype, email, and presentation tools like GoToMeeting can make instant communication and organized meetings possible. Furthermore, the use of technology has significantly improved in establishing personal connections.

However, according to a recent study, the use of technology has drawbacks too. It is said that internet technology in business decreases the personal aspect of business relationships. Many debate that technology has distorted the line between professional and private lives. With the labor so in some cases you will receive lower wages for a job that should be paying a higher rate. Not everyone considers the fact that the ones who are able to take advantage of all that globalization has to offer are the people who have the money to take advantage of it, unfortunately for the ones with little or no money are left in a cycle of poverty because they cannot afford to utilize the benefits of globalization. In some cases companies take advantage of cheap labor in other locations, which abolishes local industries because these local companies cannot compete with wages bigger multinational companies offer.

In General, it is apparent that there are both positive and negative effects of globalization and many of these effects are much more complex and multi-dimensional. There is far more that could be debated on the benefits and drawbacks of globalization, Globalization is currently affecting our lives more and more every day and has immense implications on the way we live our lives.

\section{Conclusion}

Conclusively, the article published by “OPPOSINGVIEWS”, written by Oneil Williams has analytically studied the topic "How Has Technology Impacted the Global Business Environment?" The article has provided examples of different organization for referable purposes, which has further made the article more consistent and relatable. In general, the body of the article, content, strengths and weaknesses of the article were well assessed and appraised. The article further analyzed the advantages and disadvantages of both operating in a global business market and the it's pros and cons to the general public. Therefore the article provided wide ranging information. Despite the fact that it was a short article in general, the article has managed to cover and convey the core information of the topic. 


\section{Recommendation}

I believe that technology has had a tremendous impact upon the global business environment. Therefore, I would recommend that small organizations who wish to grow in the global business market should consider outsourcing their activities in order to reduce their costs and place emphasis on the business to do their best. That way, organizations will provide more job opportunities and simultaneously decrease the rate of unemployment. Furthermore, large organizations who wish to reduce the impact of competition should focus on technologies such as the Internet (social media), mobile phones and customer relationship management systems which are fundamental and critically affect the way companies communicate with potential customers.

\section{References}

[1.] Main source:Oneil Williams. (13th July 2015). How Has Technology Impacted the Global Business Environment?, Available: http://science.opposingviews.com/technology-impacted-globalbusiness-environment-1372.html. Last accessed 08th January 2016.

[2.] Acemoglu, D., Johnson, S. and J. A. Robinson (2001), "The Colonial Origins of Comparative Development: An Empirical Investigation" American Economic Review, 91, pp. 1369-1401. Last accessed 22nd January 2016.

[3.] Boter, H. and C. Holmquist (1996) Industry Characteristics and Internationalization Process in Small Firms, Journal of Business Venturing, 11:471-87. Last accessed 17th January 2016.

[4.] Boundless. “Impact of Technology on Marketing.” Boundless Marketing. Boundless, 21 Jul. 2015. Retrieved 22 Jan. 2016 from: https://www.boundless.com/marketing/textbooks/boundless-marketingtextbook/the-marketing-environment-3/technology-32/impact-of-technology-on-marketing-170-7298/.

Last accessed 22nd January 2016.

[5.] Brooks, I., Weatherston, J., \& Wilkinson, G. (2010). The International Business Environment 2e. Pearson Education. Last accessed 15th January 2016.

[6.] Cameron, G., Proudman, J. and Redding, S. (2005) Technological Convergence, R\&D, Trade and Productivity Growth, European Economic Review, 79: 775-807. Last accessed 17th January 2016.

[7.] Dunne, T., M.J. Roberts, and L. Samuelson (1988) '"Patterns of Firm Entry and Exit in U.S. Manufacturing Industries,"', The Rand Journal of Economics, 19(4), pp. 495-515. Last accessed 15th January 2016.

[8.] Klapper, L., and I. Love, (2004), “Corporate Governance, Investor Protection and Performance in Emerging Markets”, Journal of Corporate Finance, Vol. 10, No.5, November, 703-728. Last accessed 23rd January 2016.

[9.] Madhok, A. (1998) "'The nature of multinational firm boundaries: Transaction costs, firm capabilities and foreign entry mode”. ', International Business Review, 7(3), pp. 259-290. Last accessed 20th January 2016.

[10.] Melissa Centurio Lopes (2013) Five globalization risks and how to manage them, Available at: http://blogs.oracle.com/eppm/entry/five_globalisation_risks_and_how. Last accessed 10th January 2015.

[11.] Parente, S. L. and Prescott, E. C., (1994) "Barriers to Technology Adoption and Development," Journal of Political Economy, Vol 102(2), pp 298-321. Last accessed 23rd January 2016.

[12.] Pearce, J., \& Robinson, R. (2005). Strategic management (9th ed.). New York: McGraw-Hill. Last accessed 15th January 2015.

[13.] Sachs, J. and A. Warner (1995), 'Economic Reforms and the Process of Global Integration', Brookings Papers on Economic Activity, 1, 1-118. Last accessed 23rd January 2016.

[14.] Schmidt, P. (1988), “Estimation of a Fixed-Effect Cobb-Douglas System Using Panel Data,” Journal of Econometrics, 37, 361-380. Last accessed 17th January 2016.

[15.] Seitz, J. L., \& Hite, K. A. (2011). Global Issues. Wiley-Blackwell. Last accessed 16th January 2016. 